\title{
Mukjizat Numerikal Al-Quran
}

\author{
Ari Puspita Harsoyo \\ Jurusan Tadris Matematika, Institut Agama Islam Negeri (IAIN) Tulungagung \\ Jl. Mayor Sujadi Timur No. 46 Tulungagung \\ e-mail: aripus00@gmail.com
}

\begin{abstract}
ABSTRAK
Keajaiban Al Quran dilihat dari sisi kandungannya yang telah banyak ditulis dan diketahui, tetapi keajaiban dilihat dari bagaimana Al Quran di tulis atau disusun mungkin belum banyak yang mengetahui. Orang-orang non-muslim khususnya kaum orientalis barat sering menuduh bahwa Al Quran adalah buatan Muhammad. Padahal kalau kita baca Al Quran ada ayat yang menyatakan tantangan kepada orang-orang kafir khususnya untuk membuat buku atau kitab seperti Al Quran dimana hal ini tidak mungkin akan dapat dilakukannya meskipun jin dan manusia bersatu padu membuatnya. Matematika adalah bahasa universal ilmu pengetahuan. Allah telah mendeskripsikan matematika dalam Al Quan dengan angka-angka yang memiliki keterkaitan erat dengan penciptaan dan kehidupan. bagian dari karakteristik ajaib dari Al-Qur'an yang kita telah melihatnya ke sejauh ini, juga berisi apa yang bisa kita sebut " mukjizat matematika . " Ada banyak contoh dari aspek Al-Qur'an yang menarik ini . Salah satu contoh dari hal ini adalah jumlah pengulangan kata-kata tertentu dalam Al-Qur'an . Beberapa kata yang terkait mengejutkan diulang jumlahnya yang sama beberapa kali .
\end{abstract}

\begin{abstract}
The miracle of the Qur'an is seen from the side of its contents that have been written and known, but the magic seen from how the Qur'an is written or composed may not have much to know. Non-Muslims especially western orientalists often allege that the Qur'an is made by Muhammad. Yet if we read the Qur'an there is a verse that states the challenge to the unbelievers, especially to make books or books such as $\mathrm{Al}$ Quan where this is not possible will be able to do even if jinn and humans unite to make it. Mathematics is the universal language of science. Allah has described mathematics in Al Quan with numbers that are closely related to creation and life. part of the miraculous characteristics of the Qur'an that we have seen so far, also contains what we might call "the miracle of mathematics. "There are many examples of this interesting aspect of the Qur'an. One example of this is the number of repetitions of certain words in the Qur'an. Some surprisingly related words are repeated the same number several times.
\end{abstract}

Kata Kunci: Al Quran, Mukjizat angka, matematika dalam Al Quran

\section{PENDAHULUAN}

Al Quran al karim memilki kedudukan yang fundamental dalam agama Islam.Al-Qur,an merupakan sumber hukum pertama dan yang paling utama bagi umat islam. Semua hukum yang berlaku dalam islam tidak boleh bertentangn dengan Al-Quean untuk menurunkan hukum yang lainnya. Di samping Al-quran sumber hukum islam, alquran juga merupakan mukjizat nabi Muhammad saw yang terbesar dibandingkan dengan kemukjizatan nabi Muhammad yang lainnya atau juga bila dibandinkan dengan kemukjizatan nabi-nabi yang lain. Kemukjizatan Al-quran 
belaku sepanjan zaman tanpa dibatasi oleh ruang dan waktu. Ini tentu berbeda dengan mukjizatmukjizat yang lainnya.

Ada banyak aspek yang menjadikan al-Quran sebagai suatu mukjizat. Aspek tersebut antara lain dari segi bahasa, isyarat-isyarat ilmu pengetahuan dan teknologi pemberitaan yang gaib. Disamping aspek tersebut, banyak aspek lain yang menunjukan kemukjizatan al-Quran antara lain tentang al-qurean sebagai petunjuk bagi umat manusia dan juga pengaruh terhadap psikologis dan jiwa manusia baik yang mendengar, membaca atau memahaminya. Alqur"ean adalah mukjizat abadi nabi Muhammad saw yang dengannya seluruh umat manusia dan jin ditantang untuk membuat yang serupa alqurean, sebuah atau sepuluh surah yang sama dengan surah yang yang ada didalamnya.

Banyak orang-orang yang ragu terhadap kebenaran dan kemukjizatan alquran dari zaman dahulu hingga sekarang. Banyak diantara mereka yang mengira bahwa Al Quran hanyalah bikinan nabi Muhammad saw bukan sebagai wahyu Allah swt. Oleh karenanya itulah Allah swt memberikan tantangan terhadap orang yang yang meragukan al-Qur"an

Gagasan mukjizat angka bermula dengan kepercayaan bahawa al-Qur'an telah disusun rapi oleh pengarangnya dari semua aspek. Penyelidik dan peneliti al-Qur'an di kalangan generasi awal telah merasakan adanya sesuatu yang unik berkenaan dengan kesimbangan bilangan dan angka dalam al-Qur'an. Pengiraan dan pengamatan telah berlaku lebih awal sebelum istilah dan konsep mukjizat angka muncul sebagaimana dibincangkan dalam topik sebelum ini. Ungkapan mukjizat angka hanya muncul pada abad ke 20 Masihi atau abad ke 15 Hijri. Orang pertama dipercayai mula menggunakan ungkapan ini adalah 'Abd al-Razzaq Nawfal. Beliau menulis buku dengan judul al-I'jaz al'Adadi li al-Qur'an (Mukjizat Angka Bagi al-Qur'an). Tempoh penulisannya karya ini adalah antara tahun 1965-1987. ${ }^{1}$

Dari latar belakang diatas penulis mengambil rumusan masalah yaitu : 1) bagaimana sejarah angka ?,2) bagaimana keterkaitan antara angka-angka dalam Al Quran terhadap penciptaan alam dan isinya? 3) apa bukti bahwa terdapat mukjizat numerik dalam Al Quran ?

\section{METODE PENELITIAN}

Dalam menyusun artikel ini, penulis menggunakan metode diskriptif jenis penelitian Library Research, penulis menggunakan metode deskriptif dengan langkah berikut; pertama penulis mengumpulkan bahan bacaan terkait dengan judul artikel, dari berbagai sumber bacaan dan juga

${ }^{1}$ Mohammad Sondon Arfando, Misteri Angka Dibalik Alquran (Jakarta: Prestasi Pustaka, 2008). 
internet atau media lain, kedua hasil bacaan itu kemudian dianalisa dan dipaparkan kembali sesuai data yang terkumpul. Ketiga, menarik kesimpulan dari seluruh penjelasan dalam artikel ini.

\section{HASIL DAN PEMBAHASAN}

\section{Sejarah angka}

Sejak berabad abad lampau sesungguhnya sudah banyak mmperhatikan mengenai angka angka dalam al Quran. Dr. Ghanem Al-Hamad. Pemeriksa dari Al-Bayan fi 'Ad Ayel-Quran (penghitungan ayat al Quran yang pertama) ole Abu Amru Al-Dani menyebutkan 36 buku ilmu pengetahuan dari angka-angka didalam al-Quran . angaka adalah suatu suatu hal yang tidak dapat dipisahkan dari kehidupan manusi.bagaimana tidak, setiap manusia mempunyai satu kepala, 2 tangan, 2 kaki, dan seterusnya. Namun hakikatnya, tidak sesederhana itu. sejarahnya dimulia dari ketika orang Mesir kuno yang pada mulanya tidak mengenal angka, karena mereka lebihmemperhatikan lukisan daripada hitungan. Tulisan heroglipnya digunakan untuk menggambar sesuatu. Misalnya seorang istri pergi, dilukiskan dengan seorang perempuan sedang berjalan, dan sakit dilukiskan dengan perempuan sedang tidur.

Ketika angka/ bilangan berkembang, lukisanpn berulang. Saat ingin mengatakan saya datang dengan istri-istri saya 3 orang ia melukiskan seorang laki-laki berjalan dengan gaya membungkuk di ikuti 3 perempuan dengan paras jelek, dan jika sedang berlibur bersama 3 orang kekasihnya, ia melukis laki-laki tidur bersandar pada 3 orang perempuan molek dan centil. Akan tetapi masalah muncul kemudian apabila angka tersebut semakin membengkak, bagaimana seorang pedagang di Alexandaria misalnya memesan 5000 ekor ikan ? sedangkan untuk menggambar 5000 ekor ikan tersebut sudah pasti akan mengkonsumsi semua kertas papirus yang ada di seluruh mesir.

Bangsa Irak yang terkenal pemalas memiliki espresi lain, mereka menciptakan hurup bunyi. Misalnya menggambar 3 ekor ikan dengan menuliskan : tiga ekor ikan , 1000 ekor ikna menjadi seribu ekor ikan . menyusul bangsa romawi memperkenalkan angka-angkanya yang khas dengan garis-garis horizontal, III artinya tiga, V artinya lima dan seterusnya. Namun angka-angka inipun tak luput dari kelemahan. Ia akan terbentur disaat berhadapan dengan proses hitung menghitung. Bagaimana membagi, menmbah dan mengali ? disini dibutuhkan angka pembantu. Dari situlah kemudian disempurnakan lagi oleh ilmuan India dengan memperkenalkan telor sebagai indikasian angka nol. Sepuluh ribu orang india meninggal karena kelaparan menuliskan anga 1 dengan empat butir telur dibelakangnya $=10000$. Demikian ilustrasi tentang kronologi perkembangan angka berdasarkan periodiknya hingga yang kita kenal sekarang ini. ${ }^{2}$

\section{Keterkaitan angka dalam Al Quran}

Angka adalah ruh dari matematika, sebuah bahasa murni ilmu pengetahuan (linguapura) yang diyakini oleh Carl sagan, sorang fisikawan sebagai bahasa universal alam semesta.

\footnotetext{
${ }^{2}$ Arfando.. 16-18.
} 
Matematika bukan ciptakan manusia- manusia berintelegensi tinggi seperti Euclid Phytagoras, Archimedes, Al-Khawarizmi , Galileo, kepler ataupun Stephen Hawking. Matematikawan tidaklah menciptakan matematika, namun mereka menemukn adanya aturan atau persamaan matematika dalam segala hal yang diciptakan Alloh SWT.

Al Quran mengandung mukjizat, simbol-simbol makna yaitu lafadz-lfadznya juga merupakan mukjizat. Untuk membuktikan kebenaran mukjizat Al Quran, dilakukan berbagai cara, salah satunya dengan menghubungkan Al- Quran dengan berbagi macam ilmu pengetahuan.

Dari kajian terhadap teks dan naskah al-Qur'an telah lahir suatu pengetahuan tentang mukjizat al-Qur'an yang berupa bilangan atau angka tertentu yang menjadi rumus dalam susunan ayat/ surat al-Qur'an.Mukjizat ini disebut dengan i‘jāz 'adad̄̄ (mukjizat matematis).Pada kajian 'ulūmal-Qur'ān klasik, jenis mukjizat ini belum dibahas secara eksplisit dalam pembahasan wajh al-i'jāz(segisegi kemukjizatan al-Qur’an).Namun, isyarat adanya wacana mukjizat ini ditunjukkan dalam segi kebahasaan secara implisit. Secara lebih spesifik, diskursus i‘jāz ‘adadī dimulai dengan berbagai pembahasan tentang huruf-huruf muqaththa'ah, pada awal-awal surat tertentu. Selanjutnya, diskursus adanya mukjizat angka-angka dalam al-Qur'an dibuktikan oleh beberapa peneliti mutakhir yang memiliki konsen terhadap rahasia angka-angka dalam al-Qur'an, sehingga hasilnya diketahui secara luas oleh umat Islam dan mendapat apresiasi dari penulis ilmu alQur'an.Adanya apresiasi dalam 'ulūm al-Qur'ān menunjukkan bahwa kajian i'jāz 'adadīdapat disandingkan dengan kajian mukjizat al-Qur'an lainnya.Pengetahuan ini semakin berkembang pada abad ke-19 hingga sekarang sebagai akibat dikenalnya sistem komputerisasi.Kemajuan ilmu pengetahuan yang berkembang pesat turut mempengaruhi perkembangan penelitian tentang mukjizat angka-angka ini. ${ }^{3}$

\section{Mukjizat numerik al-quran}

Al-Quran adalah kalam Allah yang merupakan sebuah Mu'jizat. Tidak ada yang menandingi keindahan bahasa Al-Quran dan keindahan ketika kita melantunkan Al-Quran. Banyak orang yang hatinya tergetar jika di bacakan ayat-ayat Al-Quran, sehingga kemudian dia mendapatkan risalah kebenaran. Al-Quran adalah satu-satunya kitab yang terjaga keasliannya walau telah diturunkan 14 abad yang lalu. Banyak usaha-usaha yang di lakukan oleh orang-orang kafir untuk memalsukan Al-Quran, namun usaha itu selalu kandas. Al-Quran yang berjumlah 30 juz, 112 surat, 6666 ayat dan 51.900 kata itu dengan mudah di hafalkan oleh orang-orang yang beriman dan mempunyai hati yang bersih. AlQuran adalah sumber ilmu yang tidak pernah ketinggalan zaman bahkan selalu mendahului zaman, karena kebenarannya baru terbukti ketika zaman sudah mampu menciptakan tekhnologi. Keajaiban lain dari Al-Quran yang tak kalah mencengangkan adalah bahwa AlQuran ternyata tersusun menurut perhitungan Matematis yang sangat teliti dan sangat

\footnotetext{
${ }^{3}$ Uun Yusufa, "Mukjizat Matematis Dalam Alquran,” Hermeunetik 8, no. 2 (2014): 346.
} 
cerdas!!

Berikut ini sejumlah perhitungan yang benar-benar merupakan mukjizat.

a) Kata "Yaum" (hari) dalam bentuk tunggal disebutkan sebanyak 365 kali, yang sama jumlahnya dengan jumlah hari pada tahun Syamsyiyyah

b) Kata "Yaum" (hari) dalam bentuk jamak sebanyak 30 kali, sama dengan jumlah hari dalam satu bulan

c) Kata "Syahr" (Bulan) sebanyak 12 kali, sama dengan jumlah bulan dalam satu tahun.

d) Kata "Sab'u (minggu) disebutkan 7 kali, sama dengan jumlah hari dalam satu minggu

e) Jumlah "Saah" (jam) yang didahului dengan "Harf" sebanyak 24 kali, sama dengan jumlah jam dalam satu hari

f) Kata "Sujud" disebutkan 34 kali, sama dengan jumlah rakaat dalam sholat 5 waktu

g) Kata "Shalawat" disebutkan 5 kali, sama dengan jumah sholat wajib sehari semalam

h) Kata "Aqimu" yang diikuti kata "Shalat" Sebanyak 17 kali, sama dengan jumlah rakaat shalat fardhu.

i) Kata "al-Dunya" disebutkan sebanyak 115 kali, begitu juga kata "al-Akhirah" sebanyak 115 kali

j) Kata " al-Israf" disebutkan 23 kali, begitu juga kata kebalikannya "al-Sur'ah"

k) Kata "Malaikat" disebutkan 88 kali, kata kebalikannya "al-Syayathin" juga 88 kali

1) Kata "al-Sulthan" disebutkan 37 kali, kata kebalikannya "al-Nifaq" juga 37 kali

m) Kata "Harb" (panas) sebanyak 4 kali, kebalikannya "al-Bard" (dingin) juga 4 kali

n) Kata "al-Harb" (perang) sebanyak 6 kali, kebalikannya "al-Husra" (tawanan) 6 kali

o) Kata "al-Hayat" (Hidup) sebanyak 145 kali, kebalikannya "al-Maut" (mati) 145 kali

p) Kata "Qalu” (mereka mengatakan) sebanyak 332 kali, kebalikannya "Qul” (katakanlah) juga sebanyak 332 kali

q) Kata "al-Sayyiat" (keburukan) yang menjadi kebalikannya kata "al-Shahihat" (Kebajikan) masing-masing 180 kali

r) Kata "al-Rahbah" (cemas/takut) yang menjadi kebalikan kata "al-Ragbah" (harap/ingin) masing-masing 8 kali

s) Kata "al-Naf'u" yang menjadi kebalikan kata "al-Fasad" masing-masing 50 kalI

t) Kata "al-Nas" yang menjadi kebalikan kata "al-Rusul" masing-masing 368 kali

u) Kata "al-Asbath" yang menjadi kebalikan kata "al-Awariyun" masing-masing 5 kali

v) Kata "al-Jahr" yang menjadi kebalikan kata "al-Alaniyah" masing-masing 16 kali

Masih banyak lagi yang tidak dapat desebutkan satu persatu, sekarang kita lakukan perhitungan seagai berikut:

a. Dengan mencari persentase jumlah kata "bahr" (lautan) terhadap total jumlah kata (bahr dan barr ) kita dapatkan : $\frac{32}{45} \times 100 \%=71.1111111 \%$

b. Dengan mencari persentase jumlah kata "barr (daratan) terhadap total jumlah kata (bahr dan barr) kita dapatkan : $\frac{13}{45} \times 100 \%=28.888888889 \%$ Kita akan mendapatkan bahwa Allah SWT. Dalam Al-Quran pada 14 abad yang lalu menyatakan bahwa persentase air di bumi adalah $71.11111111 \%$, dan persentase daratan adalah 28.8888888889 , dan ini adalah rasio yang riil dari air dan 
daratan.

Itulah sebagian kecil keajaiban dan kemukjizatan Al-Quran. Keajaiaban yang lain merupakan misteri yang akan insyaAllah akan dipecahkan oleh orang-orang yang berilmu. ${ }^{4}$

\section{KESIMPULAN}

Al-Quran mengandung mukjizat, simbol-simbol mana yaitu lafadz-lafadznya juga merupakan mukjizat. Untuk membuktikan kebenaran mujizat Al-Quran dengan berbagai macam ilmu pengetahuan.

Salah satu jenis mukjizat dari Al-Quran adalah i'jaz 'abadi (mukjizat yang besifat bilangan). I'jaz 'abadi inilah yang kemudian dijadikan rujukan sebagai sebuah pendekatan pembuktian mukjizat baru, yaitu dengan ilmu matematika. Pembuktian Al-Quran dengan ilmu-ilmu sains non-matematik sangat berbeda dengan pembuktian secara matematika. Matematika membuktikan kebenaran Al-Quran bukan dengan observasi terhadap alam, namun dengan mencari titik temu dan keseimbangan. Bilangan dalam Al-Quran . diantaranya ditemukannya keseimbangan jumlah kata syahr (bulan) sebanyak 12 kali, sholawat (jama' dari kata sholat) adalah 5 kali. Ad-dunya dan Al-akhiroh yang disebutkan dalam frekuensi yang sama, yitu 115 kali.

Banyak sekali hal-hal yang menarik yang menjadikan matematika Al-Quran semakin banyak dipelajari dan di dalami oleh masyarakat. Matematika Al-Quran dapat menjawab banyak pertanyaan - pertanyaan dibenak umat. Yang membuat masyarakat bisa lebih meyakini kebenaran Al-Quran sebagai kitab suci yang diwahyukan Allah melalui kekasih-Nya Muhammad saw. Bahwasanya Al-Quran bukanlah rekayasa mahluk, bahkan walaupun manusia dan jin bersatu padu membuatnya.

\section{DAFTAR RUJUKAN}

Arfando, Mohammad Sondon. Misteri Angka Dibalik Alquran. Jakarta: Prestasi Pustaka, 2008.

"No Title," n.d. https://numberquran.blogspot.com/2018/01/misteri-angka-angka.html.

Yusufa, Uun. "Mukjizat Matematis Dalam Alquran.” Hermeunetik 8, no. 2 (2014): 346.

4 “No Title," n.d., https://numberquran.blogspot.com/2018/01/misteri-angka-angka.html. 